\title{
Isolation and characterization of a new subspecies of Mycobacterium chelonei infectious for salmonid fish
}

\author{
C. K. Arakawa \& J. L. Fryer \\ Department of Microbiology, Oregon State University; \\ Corvallis, Oregon 97331-3804, USA
}

\begin{abstract}
Rapidly growing, nonchromogenic mycobacteria were isolated from salmonid fish at five locations in the states of Oregon and Montana, USA. The isolates were characterized by biochemical, physiological, genetic and mycolic acid properties, then subjected to taxonomic analysis. Detection of mycobacterial mycolic acids and a percent guanine plus cytosine value of $63 \pm 1.7 \mathrm{~mol} \%$ confirmed that the isolates belong to the genus Mycobacterium. The internal similarity of the isolates was $94,2 \pm 3.4 \%$. None of the isolates grew at $37^{\circ} \mathrm{C}$. A comparison of their properties with those of other rapidly growing, nonchromogenic and photochromogenic mycobacteria was made. The salmonid isolates showed a relationship to $M$. chelonei subspecies chelonei and $M$. chelonei subspecies abscessus, but had biochemical properties which were intermediate to these two subspecies. Acid methanolysates of the salmonid isolates, analyzed by two dimensional thin-layer chromatography, produced lipid patterns identical to those of both subspecies of $M$. chelonei. Sufficient differences in biochemical properties and the inability to grow at $37^{\circ} \mathrm{C}$ suggest these isolates be regarded as a new subspecies of $M$. chelonei. We propose the name $M$. chelonei subspecies piscarium subsp. nov. ( $\mathrm{L}$, adj. piscarius of fish). The isolates were not infectious for mice. Experimental infections were produced in juvenile salmonid fish. The occurrence of mycobacterial infections in selected salmonid populations from Oregon hatcheries and the Pacific Ocean ranged from 0 to $26 \%$.
\end{abstract}

\section{INTRODUCTION}

Tuberculosis in Pacific salmonids was first observed in adult fall chinook salmon (Oncorhynchus tshawytscha) returning to the Bonneville Hatchery, Oregon in 1952 (Wood \& Ordal, 1958). Subsequent studies revealed the geographic distribution of the disease in California, Oregon, Washington, and Alaska in a wide range of host species belonging to the Salmonidae. Although a true assessment of losses was not determined, the disease was believed to have had an adverse effect on populations of Pacific salmonids.

Tuberculosis was generally associated with fish of hatchery origin and investigators suspected the inclusion of raw carcasses and viscera of adult salmon in the diet of juveniles as the primary source of infection (Ross et al. 1959; Wood \& Ordal, 1958). When this practice was discontinued and only pasteurized salmon products were used in the diet, the incidence was markedly reduced (Fryer \& Sanders, 1981).

Ross $(1960,1970)$ noted the difficulty in culturing the acid-fast bacterium from tissue of adult salmonids, despite the presence of large numbers of cells. One of us (J. L. Fryer) sampled more than 2000 adult fish with gross signs of mycobacteriosis in 1958 and 1959 
but no isolates were obtained on 23 types of media. It is believed the few isolations made by various investigators (Frost, 1968; Ross, 1960) were not of the etiological agent associated with salmonid tuberculosis in the 1950's (Wood \& Ordal, 1958). These isolated strains were not extensively studied and their taxonomic position was not properly determined (Ross, 1970). In this study, the isolates obtained from infected juvenile and adult salmonids grew readily on mycobacterial and other general bacteriological media, e.g. Tryptic Soy Agar (TSA) and Brain Heart Infusion (BHI) Agar. This further suggests these isolates differ from the causative agent of salmonid tuberculosis observed in the 1950 's.

The purposes of this study were to: (1) characterize the strains of mycobacteria that have been isolated from infected salmonids by an analysis of their biochemical , physiological, genetic and mycolic acid properties and (2) to determine their taxonomic position in relation to other members of the genus Mycobacterium.

\section{MATERIALS AND METHODS}

\section{Bacterial strains}

The 6 isolates of acid-fast bacteria used in this study were all obtained from salmonids (Table 1). Known species of Mycobacterium which have been associated with disease in fish were included for comparison. These additional cultures were: $M$. fortuitum ATCC $6841^{\mathrm{T}}$, ATCC 9820; $M$. salmoniphilum ATCC 13756; $M$. chelonei ATCC 14472; $M$. chelonei subspecies chelonei ATCC $19235^{\mathrm{T}}$ i M. chelonei subspecies abscessus ATCC $19977^{\mathrm{T}}$; and $M$. marinum NCTC $927^{\mathrm{T}}$. Nocardia asteroides ATCC $19247^{\mathrm{T}}$ was

Table 1. Isolates of mycobacteria obtained from salmonids used in this study

\begin{tabular}{|c|c|c|c|}
\hline \multicolumn{2}{|c|}{$\begin{array}{l}\text { Isolate } \\
\text { designation }\end{array}$} & Host & $\begin{array}{l}\text { Year } \\
\text { isolated }\end{array}$ \\
\hline $\mathrm{BAN}^{*}$ & Bandon Hatchery, Oregon, USA & Cutthroat trout, adult Salmo clarki & 1964 \\
\hline SIL** & Siletz River Hatchery, Oregon, USA & $\begin{array}{l}\text { Coho salmon, juvenile Oncorhynchus } \\
\text { kisutsch }\end{array}$ & 1966 \\
\hline AUS-561* & Snobs Creek Hatchery, Australia & $\begin{array}{l}\text { Fall Chinook salmon, adult } \\
\text { Oncorhynchus tshawytscha }\end{array}$ & 1969 \\
\hline ER & Elk River Hatchery, Oregon, USA & $\begin{array}{l}\text { Fall Chinook salmon, juvenile } \\
\text { O. tshawytscha }\end{array}$ & 1981 \\
\hline TRA-23 & Trask River Hatchery, Oregon, USA & Coho salmon, juvenile $O$. kisutsch & 1982 \\
\hline $\begin{array}{l}\text { MONT** } \\
\text { * Isolated } \\
* \text { Isolated } \\
* \text { Isolated } \\
\text { * Infected } \\
\text { Universi } \\
\text { tissue in }\end{array}$ & $\begin{array}{l}\text { Missouri River, Montana, USA } \\
\text { by Dr. J. L. Fryer } \\
\text { by G. D. Frost (1968) } \\
\text { by Dr. L. D. Ashburner (1977) } \\
\text { tissue provided by Dr. M. Rinaldi, } \\
\text { ty, Bozeman, Montana; isolated in } \\
\text { juvenile steelhead trout (Salmo gair }\end{array}$ & $\begin{array}{l}\text { Department of Microbiology, Montan } \\
\text { our laboratory after blind passage of ir } \\
\text { dneri) }\end{array}$ & $\begin{array}{l}\text { na State } \\
\text { infected }\end{array}$ \\
\hline
\end{tabular}


also compared. $M$. salmoniphilum is not recognized by the Eighth Edition of Bergey"s Manual (Runyon et al., 1974) and differs from the strains described by Ross (1960).

\section{Characterization of strains}

Colony morphology and growth at selected temperatures were observed on Ogawa egg (Tsukamura, 1961) and Sauton's (Tsukamura, 1965) media. Generation times and optimum growth temperature were done by measuring the optical density of the Bandon isolate (BAN) in Dubos TB broth (Difco). Pigment production in the dark and photoactivity were also tested (Tsukamura, 1966).

The following biochemical characteristics were determined: acid formation from carbohydrates, utilization of organic acids as sole sources of carbon (Tsukamura, 1967b); and the ability to utilize selected nitrogen compounds (Tsukamura, 1966). Amidase activity was tested in the media described by Bönicke (1962) and ammonium was detected by the indophenol blue reaction (Hanson \& Phillips, 1981.

Nitrate reduction (Tsukamura, 1967b) sensitivity to selected dyes, niacin production (Runyon et al., 1959), tolerance to inhibitory compounds, iron uptake, hippurate hydroly" sis (Gordon \& Mihm, 1959), and arylsulfatase activity (Kubica \& Vestal, 1961) were determined. Degradation of p-aminobenzoate and p-aminosalicylate was tested on Ogawa egg medium (Tsukamura, 1961). Tween hydrolysis (Wayne et al., 1976), acid phosphatase activity (Stanford \& Beck, 1969) using Sigma 104 phosphatase substrate (Sigma Chemical Co.), and catalase activity before and after exposure to $68^{\circ} \mathrm{C}$ for $20 \mathrm{~min}$ were also tested. Growth on MacConkey agar (Difco) and reduction of potassium tellurite (Sigma) on BHI agar (Difco) were observed.

Mycolic acids were chemically detected by the method described by Kanetsuna \& Bartoli (1972) and acid methanolysate extracts of whole cells (Minnikin et al., 1980) were analyzed by two dimensional thin-layer chromatography (Minnikin et al,, 1982).

DNA was isolated by the methods described by Mizuguchi \& Tokunaga (1970) and Johnson (1981). The $G+C$ content was calculated from the thermal melting point of the DNA, as determined in a Beckman model DU-8 spectrophotometer equipped with a Tm Compuset Module, by the equation of Mandel et al. (1970).

\section{Pathogenicity}

The pathogenicity of the BAN, Elk River (ER), and Siletz (SIL) isolates in warmblooded animals was tested by injection of $0.1 \mathrm{ml}$ of a viable cell suspension at a concentration of approximately $1 \times 10^{8}$ cells per ml into groups of four Swiss-Webster mice. Two animals received the bacterium intraperitoneally (IP); the other two were injected intravenously. The mice were maintained in a biological hazard hood, monitored daily, and sacrificed after 21 days.

Experimental infections were produced in fish by $0.1 \mathrm{ml}$ IP injection of a viable cell suspension containing approximately $1 \times 10^{8}$ cells per ml. Separate groups of 18 to 21 rainbow trout (Salmo gairdneri) were maintained for 80 days in 681 tanks at $12{ }^{\circ} \mathrm{C}$ in continuous-flow fish pathogen-free water. In a separate experiment, groups of 20 juvenile chinook salmon injected with mycobacterium were maintained for 10 days in 681 tanks at $18^{\circ} \mathrm{C}$ in continuous-flow fish pathogen-free water. Each experiment 
included a control group of fish injected with $0.1 \mathrm{ml}$ phosphate-buffered saline. Survivors were sacrificed at termination of each experiment. These and all fish that died during the experiments were necropsied.

\section{Prevalence of mycobacterial infections}

Acid-fast stains of kidney tissue smears were examined to estimate the prevalence of mycobacterial infections at selected locations in Oregon and the Pacific Ocean. The Ziehl-Neelsen acid-fast stain (Paik \& Suggs, 1974) and a modified fluorescent acid-fast stain (Matthaei, 1950; Banner et al., 1982) were used. The fish were considered infected when typical acid-fast bacilli were observed in the tissue smear.

\section{RESULTS}

\section{Characterization}

Primary isolation and subcultivation on Ogawa egg medium revealed smooth, moist, creamy to buff-colored colonies (Fig. 1a). Rough colonies sometimes developed after three weeks incubation and were the usual form exhibited on Sauton's agar after five days (Fig. 1b). Microscopic examination of the strains isolated from fish and grown on Ogawa egg medium revealed pleomorphic rods, 1 to $4 \mu \mathrm{m} \times 0.3$ to $0.6 \mu \mathrm{m}$ in diameter. The cells were acid-fast and weakly Gram positive. No spores, capsules, true branching, or aerial hyphae were observed.

Visible colonies developed in 3 to 5 days at 25 and $30^{\circ} \mathrm{C}$. Growth at $10^{\circ} \mathrm{C}$ was observed 5 to 10 days after inoculation of all isolates except Montana (MONT), which grew in less than 5 days. None of the isolates grew at $37^{\circ} \mathrm{C}$ or above. Strains of Mycobacterium fortuitum grew from 25 to $42^{\circ} \mathrm{C}$ and both subspecies of $M$. chelonei grew from 10 to $37^{\circ} \mathrm{C}$. The log of the mean optical density of the BAN isolate was plotted for each temperature tested and the generation times were as follows: $36.5 \mathrm{~h}$ at $10^{\circ} \mathrm{C}, 24.3 \mathrm{~h}$ at $15^{\circ} \mathrm{C}, 14.3 \mathrm{~h}$ at $20^{\circ} \mathrm{C}, 7.4 \mathrm{~h}$ at $25^{\circ} \mathrm{C}$, and $26.7 \mathrm{~h}$ at $30^{\circ} \mathrm{C}$. The optimal growth temperature was between 20 and $25^{\circ} \mathrm{C}$ with no growth occurring after 14 days above $30^{\circ} \mathrm{C}$ or below $10^{\circ} \mathrm{C}$.

The results of 63 biochemical tests (Table 2) were analyzed by the conventional $\mathrm{n} \times \mathrm{n}$ matrix table of matching scores The internal similarity of the five isolates was 94.2 $\pm 3.4 \%$.

When compared to other rapidly growing, nonchromogenic mycobacteria, the isolates showed a relationship to the two subspecies of $M$. chelonei (Table 3). The salmonid isolates differed from $M$. chelonei subspecies chelonei by 12 properties and from $M$. chelonei subspecies abscessus by 11 properties (Table 4). These characteristics served to distinguish the salmonid isolates from the two known subspecies of $M$. chelonei. An important difference was the inability of the isolates from salmonids to grow at $37^{\circ} \mathrm{C}$.

All of the salmonid isolates and known mycobacteria examined produced precipitates of mycolic acids which melted between 45 and $65^{\circ} \mathrm{C}$. These temperatures corresponded to the melting points of mycolic acids for mycobacteria reported by Kanetsuna \& Bartoli (1972).

All of the acid methanolysate extracts of the salmonid isolates showed a pattern 

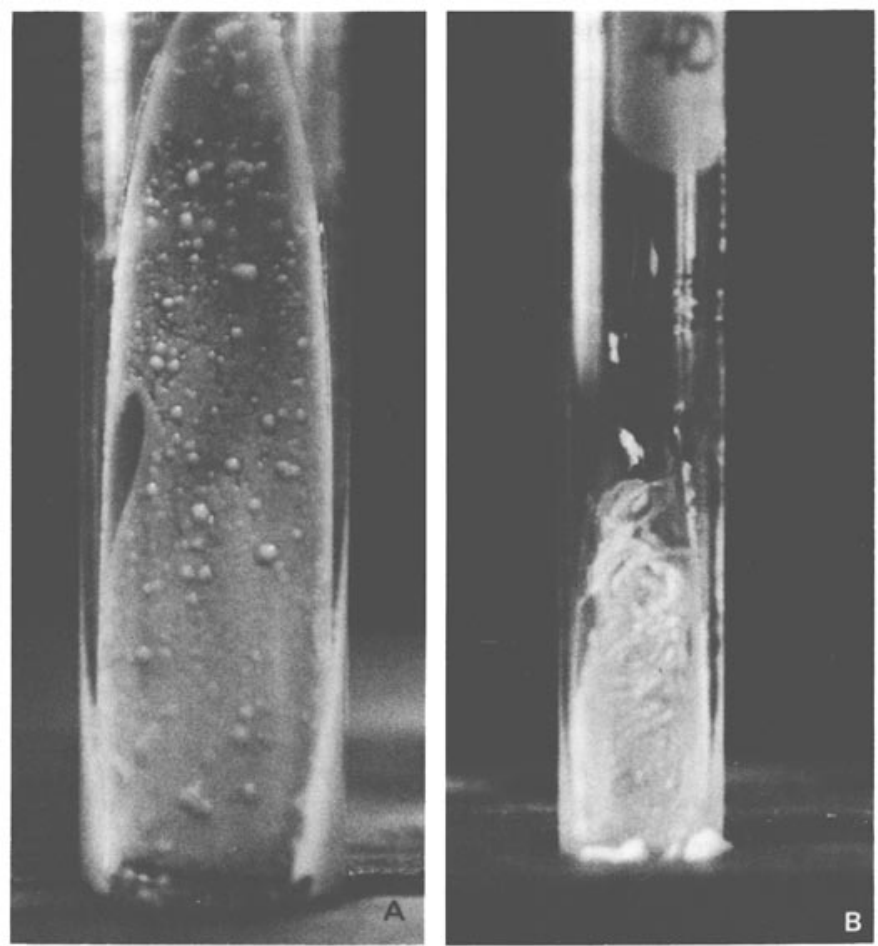

Fig. 1. Colony morphology of Bandon (BAN) isolate after 5 days at $25^{\circ} \mathrm{C}$. Nonpigmented smooth growth on Ogawa egg medium (A) and rough growth on Sauton's agar (B)

identical to those produced by strains of $M$. chelonei when analyzed by two dimensional thin-layer chromatography (Fig. 2).

The average percent guanine plus cytosine $(\% \mathrm{G}+\mathrm{G})$ of DNA of the mycobacteria isolated from salmonids ranged from 61 to $65 \%$. These values fall within $2 \%$ of the 62 to $70 \% \mathrm{G}+\mathrm{C}$ value reported for the mycobacteria (Goodfellow \& Wayne, 1982). The average $\% \mathrm{G}+\mathrm{C}$ for the salmonid isolates was $63 \pm 1.7 \%$.

\section{Pathogenicity}

After 21 days, the mice injected with cell suspensions of each of the isolates were sacrificed. None of the animals exhibited signs of infection and no gross internal lesions were visible upon necropsy, Kidney, liver and spleen tissues were processed for bacterial culture in an attempt to recover the injected organism but no isolations were made. Tissue smears of these organs did not reveal the presence of acid-fast bacteria.

Experimental infections were produced at $12^{\circ} \mathrm{C}$ in three separate lots of juvenile rainbow trout injected IP with the BAN, ER, and SIL isolates. The total loss ranged from 20 to $52 \%$ with the SIL isolates causing the greatest number of deaths. None of the fish in the control group became infected with mycobacteria. From fish that died, isolates were recovered on Ogawa egg medium and observed by Ziehl-Neelsen stain. Signs of infection were variable. Moribund fish often had swollen abdomens and hemorrhaging 
Table 2. Biochemical characteristics of five salmonid isolates studied

\begin{tabular}{|c|c|c|c|c|c|}
\hline \multirow[t]{2}{*}{ Character } & \multicolumn{5}{|c|}{ Isolates } \\
\hline & BAN & ER & SIL & TRA-23 & MONT \\
\hline \multicolumn{6}{|l|}{ Enzymatic activity } \\
\hline arylsulfatase -3 days & + & + & + & + & + \\
\hline arylsulfatase -2 weeks & + & + & + & + & + \\
\hline hippurate hydrolysis & - & - & - & - & - \\
\hline tween hydrolysis -5 days & - & - & - & - & - \\
\hline nitrate reductase & - & - & - & - & - \\
\hline acetamidase & - & - & - & - & - \\
\hline benzamidase & - & - & - & - & - \\
\hline urease & + & + & + & + & + \\
\hline isonicotinamidase & - & - & - & - & - \\
\hline nicotinamidase & - & - & - & - & - \\
\hline pyrazinamidase & - & - & - & - & - \\
\hline allantoinase & - & - & - & - & - \\
\hline succinamidase & - & - & - & - & - \\
\hline catalase & + & + & + & + & + \\
\hline catalase after $68^{\circ} \mathrm{C}$ & - & - & - & - & - \\
\hline acid phosphatase & + & + & + & + & + \\
\hline acid phosphatase after $70^{\circ} \mathrm{C}$ & - & - & - & - & - \\
\hline \multicolumn{6}{|l|}{ Utilization as sole $\mathrm{C}$-source } \\
\hline benzoate & - & - & - & - & - \\
\hline fumarate & + & + & + & - & - \\
\hline succinate & + & + & + & - & - \\
\hline citrate & + & + & + & - & - \\
\hline malonate & - & - & - & - & - \\
\hline oxalate & - & - & - & - & - \\
\hline \multicolumn{5}{|l|}{ Utilization as sole $C$ and $N$-source } & - \\
\hline benzamide & - & - & - & - & - \\
\hline nicotinamide & - & - & - & - & - \\
\hline Na-L-glutamate & + & + & + & + & + \\
\hline L-serine & + & + & + & + & + \\
\hline glucosamine hydrochloride & - & - & - & - & - \\
\hline \multicolumn{6}{|l|}{ Tolerance to } \\
\hline hydroxylamine, $250 \mu \mathrm{g} / \mathrm{ml}$ & + & + & + & + & - \\
\hline azide, $20 \mu \mathrm{g} / \mathrm{ml}$ & - & - & - & + & - \\
\hline 8-azaguanine, $250 \mu \mathrm{g} / \mathrm{ml}$ & + & + & + & + & + \\
\hline ethambutol, $5 \mu \mathrm{g} / \mathrm{ml}$ & + & + & + & + & + \\
\hline $1 \%$ sodium deoxycholate & + & + & + & + & + \\
\hline $0.1 \%$ sodium nitrite & + & + & + & - & + \\
\hline $3 \% \mathrm{NaCl}$ & - & + & + & + & - \\
\hline $5 \% \mathrm{NaCl}$ & - & - & - & - & - \\
\hline $0.1 \%$ malachite green & + & + & + & + & + \\
\hline $0.01 \%$ methyl violet & + & + & + & + & + \\
\hline $0.01 \%$ pyronin B & + & + & + & + & + \\
\hline $0.01 \%$ chlorophenol red & + & + & - & - & - \\
\hline $0.1 \%$ picric acid & + & + & + & + & + \\
\hline $0.2 \%$ picric acid & + & + & + & + & + \\
\hline para-aminobenzoate & + & + & + & + & + \\
\hline para-aminosalicylate & + & + & + & + & + \\
\hline sodium salicylate & + & + & + & + & + \\
\hline
\end{tabular}


around the vents and along the lateral surfaces. When necropsied, ascites and a white membranous material were observed around the mesenteries and adjoining viscera. The spleen, kidney and liver were the organs most often affected. In grossly infected fish the liver and kidney were pale, and white nodular lesions were seen in these organs. The spleen was usually enlarged and a deep red color. No deaths occurred after 40 days and all survivors were sacrificed 80 days after injection. Upon necropsy, splenomegaly was often observed and isolates were recovered and detected by acid-fast stain in $31 \%$ of the ER injected group, $60 \%$ of the SIL injected group, and $88 \%$ of the BAN injected group. The fish in the control group remained free of the disease.

Table 2 continued

\begin{tabular}{|c|c|c|c|c|c|}
\hline \multirow[t]{2}{*}{ Character } & \multicolumn{5}{|c|}{ Isolates } \\
\hline & BAN & ER & SIL & TRA-23 & MONT \\
\hline \multicolumn{6}{|l|}{ Growth on } \\
\hline MacConkey agar & + & + & + & + & + \\
\hline Potassium-tellurite agar & + & + & + & + & + \\
\hline \multicolumn{6}{|l|}{ Degradation of } \\
\hline para-aminobenzoate & + & + & + & + & + \\
\hline para-aminosalicylate & + & + & + & + & + \\
\hline sodium salicylate & + & + & + & + & + \\
\hline \multicolumn{6}{|l|}{ Acid production from } \\
\hline glucose & + & + & + & + & + \\
\hline arabinose & - & - & - & - & - \\
\hline dulcitol & - & - & - & - & - \\
\hline fructose & - & - & - & - & - \\
\hline galactose & - & - & - & - & - \\
\hline inositol & - & - & - & - & - \\
\hline mannitol & - & - & - & - & - \\
\hline mannose & + & + & + & + & + \\
\hline rhamnose & - & - & - & - & - \\
\hline sorbitol & - & - & - & - & - \\
\hline sucrose & - & - & - & - & - \\
\hline trehalose & - & - & - & - & - \\
\hline xylose & - & - & - & - & - \\
\hline Iron uptake & - & - & - & - & - \\
\hline Niacin production & - & - & - & - & + \\
\hline
\end{tabular}

In the second experiment, juvenile chinook salmon were injected with a cell suspension of the BAN isolate and maintained at $18{ }^{\circ} \mathrm{C}$ for 10 days. Mortality was $98 \%$ by the 10 th day after injection. Generally, no internal or external signs of infection were observed in fish that died during the first 7 days, although acid-fast bacteria were found in tissue smears or were recovered in culture. Ascites, splenomegaly, and a white membranous material around the mesenteries were observed in fish that died on the 8th to 10 th days. 
Table 3. Percent similarities between the salmonid isolates, represented by the Bandon strain, and selected species of rapidly growing mycobacteria

\begin{tabular}{|cc|}
\hline \multicolumn{1}{|c|}{ Taxon } & $\begin{array}{c}\text { Percent similarity } \\
\text { to the Bandon isolate* }\end{array}$ \\
\hline Mycobacterium chelonei ssp. abscessus & 87.2 \\
$M$. chelonei ssp. chelonei & 85.9 \\
$M$. salmoniphilum * & 79.5 \\
$M$. fortuitum (cold-water type) ** & 78.2 \\
$M$. fortuitum (type strain) & 75.6 \\
$M$. marinum & 73.1 \\
$M$. chitae & 68.1 \\
$M$. agri & 55.0 \\
M. smegmatis & 53.1 \\
Characteristics of known mycobacterial strains based on results from this study and on those \\
Edition of Bergey's Manual. Percent value expressed based on 78 characteristics \\
* Not recognized by 8th Edition of Bergey's Manual (Runyon et al., 1974) \\
\hline
\end{tabular}

Table 4. Differences in properties between the salmonid isolates, represented by the Bandon strain, and the two known subspecies of Mycobacterium chelonei. - = less than $15 \%$ strains produced positive reaction. $+=$ greater than $85 \%$ strains produced positive reaction. $\mp=15-85 \%$ strains produced positive reaction *

\begin{tabular}{|c|c|c|c|}
\hline Property & $\begin{array}{l}\text { Bandon } \\
\text { Strain }\end{array}$ & $\begin{array}{l}\text { Mycobacterium } \\
\text { chelonei subsp. } \\
\text { chelonei }\end{array}$ & $\begin{array}{c}\text { Mycobacterium } \\
\text { chelonei subsp. } \\
\text { abscessus }\end{array}$ \\
\hline Growth at $37^{\circ} \mathrm{C}$ & - & + & + \\
\hline Hippurate hydrolysis & - & + & $\Psi$ \\
\hline Nicotinamidase & - & + & 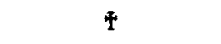 \\
\hline Pyrazinamidase & - & + & + \\
\hline Catalase after $68^{\circ} \mathrm{C}$ & - & + & + \\
\hline Acid phosphatase after $70^{\circ} \mathrm{C}$ & - & $\mp$ & - \\
\hline \multicolumn{4}{|l|}{ Tolerance to } \\
\hline azide, $20 \mu \mathrm{g} / \mathrm{ml}$ & - & - & + \\
\hline $1 \%$ sodium deoxycholate & + & - & + \\
\hline $0.1 \%$ sodium nitrite & + & - & + \\
\hline $5 \% \mathrm{NaCl}$ & - & - & + \\
\hline $0.2 \%$ picric acid & + & - & + \\
\hline Growth on potassium tellurite agar & + & - & + \\
\hline Acid from mannitol & + & - & - \\
\hline Acid from trehalose & - & + & + \\
\hline Citrate utilization as sole carbon source & + & + & - \\
\hline $\begin{array}{l}\text { Nicotinamide utilization as sole carbon } \\
\text { and nitrogen source }\end{array}$ & - & - & + \\
\hline
\end{tabular}




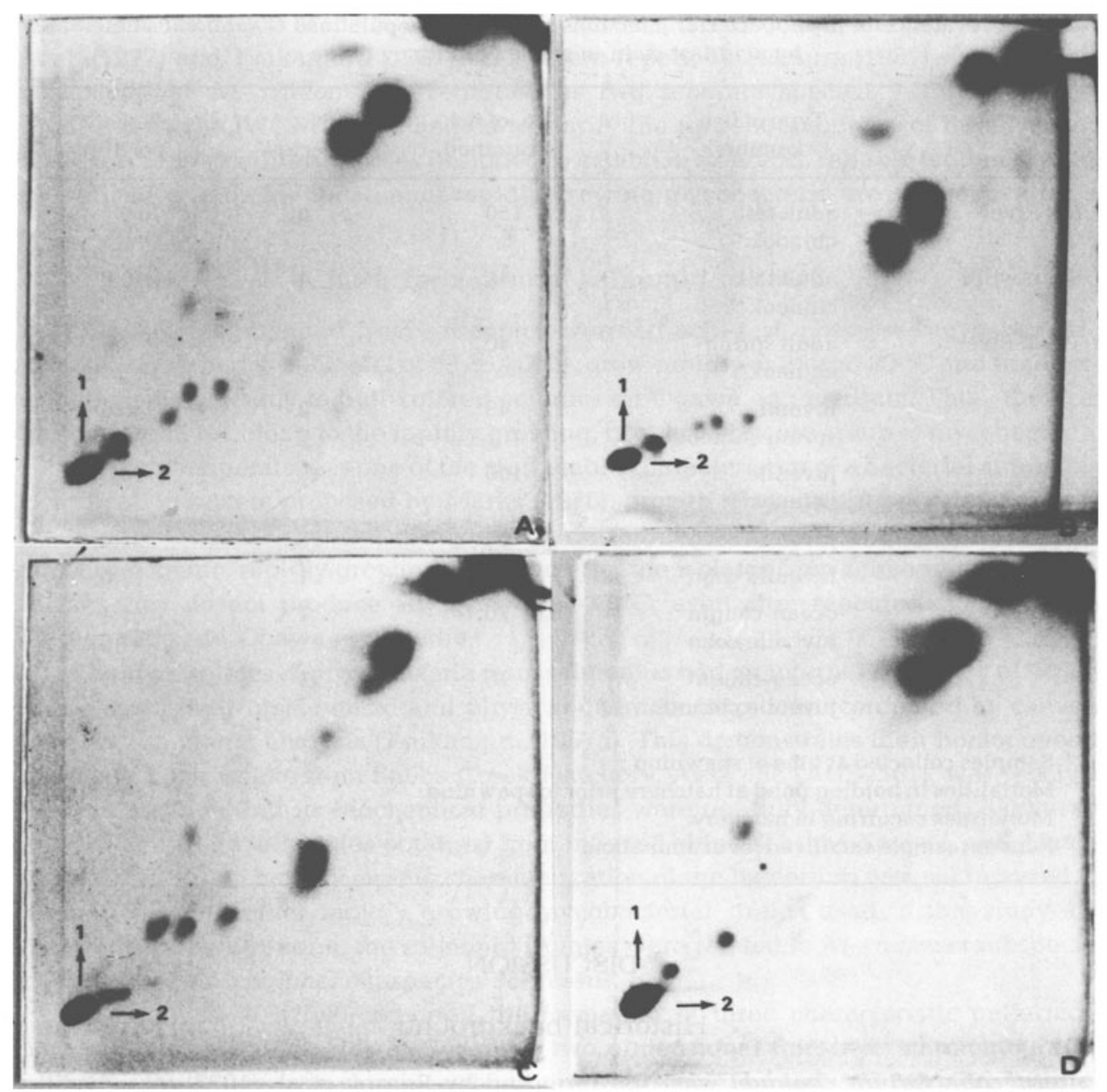

Fig. 2 Patterns produced by two dimensional thin-layer chromatography of whole-organism acid methanolysates of (A) Mycobacterium chelonei subspecies chelonei, (B) $M$. chelonei subspecies abscessus, (C) $M$. fortuitum, and (D) Bandon isolate, representing patterns produced by all of the salmonid isolates. Arrows denote direction of development: (1) petroleum ether/acetone (95:5) $(\times 3)$, (2) toluene/acetone $(97: 3)(\times 1)$. Isolates show identical lipid pattern to two subspecies of M. chelonei

\section{Prevalence of mycobacterial infections}

The prevalence of mycobacterial infections in selected populations of fish in Oregon hatcheries ranged from 0 to $26 \%$ (Table 5). During this study, access to ocean-caught juvenile salmonids presented a unique opportunity to investigate the prevalence of mycobacterial infections in fish during their salt water phase. Infections in the groups of ocean-caught juvenile coho (Oncorhynchus kisutsch) and juvenile chinook were $1.4 \%$ and $4.0 \%$ respectively (Table 5 ). 
Table 5. Prevalence of mycrobacterial infections in selected populations of salmonids determined by acid-fast stain in smears of kidney tissue

\begin{tabular}{|c|c|c|c|c|}
\hline Location & $\begin{array}{l}\text { Type of fish } \\
\text { examined }\end{array}$ & $\begin{array}{l}\text { No. of fish } \\
\text { examined }\end{array}$ & $\begin{array}{c}\text { No. } \\
\text { infected }\end{array}$ & $\begin{array}{l}\text { Percent } \\
\text { positive }\end{array}$ \\
\hline Elk River & $\begin{array}{l}\text { adult fall } \\
\text { chinook* }\end{array}$ & 150 & 0 & 0 \\
\hline Bonneville & $\begin{array}{l}\text { adult fall } \\
\text { chinook }\end{array}$ & 41 & 4 & 10.0 \\
\hline \multirow[t]{4}{*}{ Trask River } & $\begin{array}{l}\text { adult spring } \\
\text { chinook* }\end{array}$ & 40 & 1 & 3.0 \\
\hline & $\begin{array}{l}\text { juvenile } \\
\text { spring chinook }\end{array}$ & 43 & 2 & 5.0 \\
\hline & $\begin{array}{l}\text { juvenile } \\
\text { chinook }^{* 4}\end{array}$ & 100 & 10 & 10.0 \\
\hline & juvenile coho" & 64 & 13 & 26.0 \\
\hline Salmon River & juvenile coho ${ }^{*}$ & 6 & 1 & 17.0 \\
\hline \multirow[t]{2}{*}{ Pacific Ocean } & $\begin{array}{l}\text { ocean-caught } \\
\text { juvenile coho }\end{array}$ & 70 & 1 & 1.4 \\
\hline & $\begin{array}{l}\text { ocean-caught } \\
\text { juvenile chinook }\end{array}$ & 25 & 1 & 4.0 \\
\hline \multicolumn{5}{|c|}{$\begin{array}{l}\text { Samples collected at time of spawning. } \\
\text { * Mortalities in holding pond at hatchery prior to spawning. } \\
\text { * Martalities occurring in hatchery. } \\
\text { " Random sample sacrificed for examination. }\end{array}$} \\
\hline
\end{tabular}

\section{DISCUSSION}

\section{Historical background}

Mycobacterium chelonei was first proposed by Bergey et al. (1923) for a bacillus isolated from a turtle tubercle by Friedmann (Goodfellow \& Wayne, 1982). The taxonomic status of the species was revised in 1969 when it was proposed that $M$. abscessus, $M$. borstelense and $M$. runyonii be reduced to synonyms of $M$. chelonei (Tsukamura, 1981). Prior to this study, $M$. abscessus and $M$. runyonit were found to be identical while $M$. borstelense was considered a separate species or at least a variant of $M$. abscessus (Goodfellow \& Wayne, 1982). In 1972, the International Working Group on Mycobacterial Taxonomy (IWGMT) suggested that $M$. abscessus and $M$. borstelense be classified under the single name $M$. chelonei on the basis of lipid patterns, serological studies, and biochemical characteristics (Kubica et al., 1972). Two subspecies, $M$. chelonei subspecies abscessus and $M$. chelonei subspecies chelonei were recognized and distinguished by the following biochemical tests: (1) utilization of citrate as a single carbon source; (2) utilization of nicotinamide and (3) nitrite as a single nitrogen source; (4) utilization of trimethylene diamine as a single nitrogen and carbon source; (5) growth in the presence of $1 \%$ deoxycholate and (6) $5 \% \mathrm{NaCl}$. Additional biochemical tests used 
for the differentiation of the two subspecies were reported by Runyon et al. (1974), Saito et al. (1977) and Tsukamura (1981). In a recent report, Tsukamura (1981) suggested the subspecies of $M$. chelonei be regarded as two separate species. Although reports produced by the IWGMT have helped to clarify the present taxonomy of the mycobacteria, test reproducibility studies designed to establish standard, reliable methods for the identification and classification of rapidly growing mycobacteria are not yet available.

\section{Characterization of salmonid isolates}

The isolates obtained from salmonids were all acid-fast, possessed mycobacterial mycolic acids, had a \% G $+\mathrm{C}$ of $63 \pm 1.7 \%$, grew rapidly at 25 and $30{ }^{\circ} \mathrm{C}$ and produced smooth, moist, creamy to buff-colored colonies on Ogawa egg medium. Thus, they can be considered to belong to the rapidly growing, nonchromogenic group of mycobacteria.

Growth temperature is one of the most stable characteristics of a bacterial strain. In a classification system proposed by Marks (1976), growth temperature provided the basis for the fundamental division of mycobacteria found in clinical isolates. Unlike other nonchromogenic, rapidly growing mycobacteria, the isolates from salmonids are unique in that they do not produce any growth at $37^{\circ} \mathrm{C}$, even after repeated subculture on Petragnani's and Ogawa egg media.

The five isolates of mycobacteria from salmonids had an internal similarity of $94.2 \pm$ $3.4 \%$ when their biochemical and physical characteristics were compared by conventional $n \times n$ matrix analysis (Tsukamura, 1967a). This demonstrates their homogeneous nature. A sixth isolate from Snobs Creek Hatchery, Australia (AUS-561), was received late in the study and its biochemical properties were not fully determined. Ashburner (1977) identified the isolates obtained from infected chinook at the Snobs Creek Hatchery as $M$. chelonei but a complete characterization of the bacterium was not reported. In comparison with other rapidly growing mycobacterial strains used in this study and described in the literature, the salmonid isolates were related to $M$. chelonei subspecies chelonei and $M$. chelonei subspecies abscessus.

Minnikin et al. (1980) reported the formation of three characteristic patterns of mycobacterial mycolic acids analyzed by two dimensional thin-layer chromatography useful for the subgeneric classification of mycobacteria. The patterns were exemplified by: (1) $M$. tuberculosis, (2) $M$. avium, and (3) $M$. fortuitum and $M$. smegmatis which produced a single pattern. A subsequent report showed an additional pattern was produced by strains of $M$. chelonei which allowed the group to be distinguished from all other mycobacteria studied. Acid methanolysate extracts of each of the salmonid isolates produced patterns identical to the two known subspecies of $M$. chelonei. This provides further evidence that the salmonid isolates be identified with this group of mycobacteria.

With the exception of trimethylene diamine utilization, all of the tests used to distinguish the two known subspecies of $M$. chelonei were included in the characterization studies of the salmonid isolates. Based on the classification system used in this study, the isolates have biochemical properties intermediate of those reported for both subspecies of $M$. chelonei and cannot be definitively placed in either of the two subdivisions. The biochemical, physical, and lipid properties of the salmonid isolates indicate they are related to the known subspecies but are sufficiently different to be considered a new subspecies of $M$, chelonei. Mycobacterium chelonei subspecies 
piscarium subsp. nov. (L. adj. piscarius of fish) is suggested for this pathogen of salmonids.

\section{Pathogenicity of salmonid isolates}

Strains of $M$. chelonei that produced a positive arylsulfatase reaction after three days have been reported to cause disease in humans (Goodfellow \& Wayne, 1982). No observable signs of disease were produced in Swiss-Webster mice injected with viable cell suspensions of the salmonid isolates, indicating they are not pathogenic to these warm-blooded animals. The isolates, however, were arylsulfatase positive after three days and although they were unable to grow at $37^{\circ} \mathrm{C}$, growth was produced at $30^{\circ} \mathrm{C}$. This temperature corresponds to the peripheral body temperature of humans; thus, the salmonid isolates cannot be totally disregarded as potential pathogens of warm-blooded animals.

Experimental infections were produced in juvenile rainbow trout and fall chinook salmon injected with high cell concentrations of the isolates. Signs of the disease were similar to those described by Parisot (1958) and Ashburner (1977). Mycobacteria could be readily detected and recovered from fish sacrificed on the 80th day of the experiment, indicating the infection was of a chronic nature. An acute form of the disease was also observed in the group of juvenile chinook held at a higher temperature.

\section{Prevalence of mycobacterial infection}

Although diagnosis of mycobacteriosis in fish reared in Oregon hatcheries did not occur between 1964 and 1981 (Fryer \& Sanders, 1981), our observations prompted the initiation of a limited survey to estimate the prevalance of mycobacterial infections. Results indicated a low percentage of the salmonid populations examined were infected with acid-fast bacteria. Our observations of mycobacteria in juvenile and adult salmonids in both the fresh and salt water phases suggests that this infection continues throughout their life cycle.

Acknowledgement. This research was supported by the Oregon Department of Fish and Wildlife under PL89304, Anadromous Fish Act. Oregon Agricultural Experiment Station Technical Paper No. 6949 .

\section{LITERATURE CITED}

Ashbumer, L. D, 1977. Mycobacteriosis in hatchery-confined chinook salmon (Oncorhynchus tshawytscha Walbaum) in Australia. - J. Fish Biol. 10, 523-528.

Banner, C. R., Rohovec, J. S. \& Fryer, J. L., 1982. A rapid method for labeling rabbit immunoglobulin with fluorescein for use in detection of fish pathogens. - Bull. Europ. Fish Path. 2, 35-37.

Bönicke, R., 1962. Identification of mycobacteria by biochemical methods. - Bull. int. Un. Tuberc. 32, 13-68.

Frost, G. D., 1968. Oral immunization for possible control of furunculosis in fish. Masters Thesis, Oregon State Univ., Corvallis, Oregon, $59 \mathrm{pp}$.

Fryer, J. L. \& Sanders, J. E., 1981. Bacterial kidney disease of salmonid fish. - A. Rev. Microbiol. 35 , $273-298$.

Goodfellow, M. \& Wayne, L. G., 1982. Taxonomy and nomenclature. In: The biology of the mycobacteria. Ed. by C. Ratledge \& J. L. Stanford. Acad. Press, New York, 1, 471-521. 
Gordon, R. E. \& Mihm, J. M., 1959. A comparison of four species of mycobacteria. - J. gen. Microbiol. 21, 736-748.

Hanson, R. S. \& Phillips, J. A., 1981. Chemical composition. In: Manual of methods for general bacteriology. Ed. by P. Gerhardt, R. G. E. Murray, R. N. Costilow, E. W. Nester, W. A. Wood, N. R. Krieg \& G. B. Phillips. Am. Soc. Microbiol, Washington, D. C., 328-392.

Johnson, J. L., 1981. Genetic characterization. In: Manual of methods for general bacteriology. Ed. by P. Gerhardt, R. G. E. Murray, R. N. Costilow, E. W. Nester, W. A. Wood, N. R. Krieg \& G. B. Phillips. Am. Soc. Microbiol., Washington, D. C., 450-472.

Kanetsuna, F. \& Bartoli, A., 1972. A simple chemical method to differentiate Mycobacterium from Nocardia. - J. gen. Microbiol. 70, 209-212.

Kubica, G. P., Baess, I., Gordon, R. E., Jenkins, P. A., Kwapinski, J. B. G., McDurmont, C., Pattyn, S. R., Saito, H., Silcox, V., Stanford, J. L., Takeya, K. \& Tsukamura, M., 1972. A cooperative numerical analysis of rapidly growing mycobacteria. - J. gen. Microbiol. 73, 55-70.

Kubica, G. P. \& Vestal, A. L., 1961. The arylsulfatase activity of acid-fast bacilli. I. Investigation of activity of stock cultures of acid-fast bacilli. - Am. Rev. Resp. Dis. 83, 728-732.

Mandel, M. L., Igambi, L., Bergendahl, J., Dodson, M. L. \& Scheltgen, E., 1970. Correlation of melting temperature and cesium chloride buoyant density of bacterial deoxyribonucleic acid. J. Bact. 101, 333-338.

Marks, J., 1976. A system for the examination of tubercle bacilli and other mycobacteria. - Tubercle, Lond. 57, 207-225.

Matthaei, E., 1950. Simplified fluorescence microscopy of tubercle bacilli. - J. gen. Microbiol. 9, 393-398.

Minnikin, D. E., Hutchinson, I. G., Caldicott, A. B. \& Goodfellow, M, 1980. Thin layer chromatography of methanolysates of mycolic acid-containing bacteria. - J. Chromat. 188, 221-233.

Minnikin, D. E., Minnikin, S. M., Goodfellow, M. \& Stanford, J. L., 1982. The mycolic acids of Mycobacterium chelonei. - J. gen. Microbiol. 128, 817-822.

Mizuguchi, Y. \& Tokunaga, T, 1970. Method for isolation of deoxyribonucleic acid from mycobacteria. - J. Bact. 104, 1020-1021.

Paik, G. \& Suggs, M. T., 1974. Reagents, stains, and miscellaneous test procedures. In: Manual of clinical microbiology. Ed. by E. H. Lennette, E. H. Spaulding, J. P. Truant. Am. Soc. Microbiol., Washington, D. C., 930-950.

Parisot, T. J., 1958. Tuberculosis of fish. A review of the literature with a description of the disease in salmonid fish. - Bact. Rev. 22, 240-245.

Ross, A. J., 1960. Mycobacterium salmoniphilum sp. nov. from salmonid fishes. - Am. Rev. Resp. Dis. 81, 241-250.

Ross, A. J., 1970, Mycobacteriosis among salmonid fishes. In: A Symposium on diseases of fishes and shellfishes. Ed, by S. F. Snieszko. Am. Fish. Soc., Washington, D. C., $279-283$ (Spec. Publ. Am. Fish. Soc. 5).

Ross, A. J., Earp, B. \& Wood, J. W., 1959. Mycobacterial infections in adult salmon and steelhead trout returning to the Columbia River Basin and other areas in 1957, - Spec. scient. Rep. U. S. Fish. Wildl. Serv. 332, 1-34.

Runyon, E. H., Selin, M. J. \& Harris, H. W., 1959. Distinguishing mycobacteria by the niacin test. A modified procedure. - Am. Rev. Resp. Dis. 79, 663-665.

Runyon, E. H., Wayne, L. G. \& Kubica, G. P., 1974. Family II. Mycobacteriaceae Chester 1897, 63. In: Bergey's manual of determinative biology. Ed. by R. E. Buchanan \& N. E. Gibbons. Williams \& Wilkins, Baltimore, $681-701$.

Saito, H., Gordon, R. E., Juhlin, 1., Kappler, W., Kwapinski, J. B. G., McDurmont, C., Pattyn, S. R., Runyon, E. H., Stanford, J. L., Tarnok, I., Tasaka, H., Tsukamura, M. \& Weiszfeiler, J., 1977. Cooperative numerical analysis of rapidly growing mycobacteria. The second report. - Int. J. syst. Bact. $27,75-85$.

Stanford, J. L. \& Beck, A., 1969. Bacteriological serological studies of fast growing mycobacteria identified as Mycobacterium friedmanii. - J. gen. Microbiol. 58, 99-106.

Tsukamura, M,, 1961. Certain saprophytic mycrobacteria from soil sources forming a red color product from PAS. - Am. Rev. Resp. Dis. 84, 916.

Tsukamura, M., 1965. Salicylate degradation test for differentiation of Mycobacterium fortuitum from other mycobacteria. - J. gen. Microbiol. 41, 309-315. 
Tsukamura, M., 1966. Adansonian classification of mycobacteria. - J. gen. Microbiol. 15, 253-273.

Tsukamura, M. 1967a. Differentiation of mycobacteria by utilization of nitrogen compounds as simultaneous nitrogen and carbon sources. - Am. Rev. Resp. Dis. 95, 307-310.

Tsukamura, M., 1967b. Identification of mycobacteria, - Tubercle, Lond, 48, 311-338.

Tsukamura, M., 1981. Numerical analysis of rapidly growing, nonphotochromogenic mycobacteria, including Mycobacterium agri (Tsukamura 1972) Tsukamura sp. nov., nom. rev. - Int. J. syst. Bact. 31, 247-258.

Wayne, L. G., Engel, H. W. B., Grassi, C., Gross, W., Hawkins, J., Jenkins, P. A., Kappler, W., Kleeberg, H. H., Krasnow, I., Nel, E. E., Pattyn, S. R., Richards, P. A., Showalter, S., Slosarek, M., Szabo, I., Tarnok, I., Tsukamura, M., Vergmann, B. \& Wolinsky, E., 1976. Highly reproducible techniques for use in systematic bacteriology in the genus Mycobacterium: tests for niacin and catalase and for resistance to isoniazid, thiophene 2-carboxylic acid hydrazide, hydroxylamine, and p-nitrobenzoate. - Int. J. syst. Bact. 26, 311-318.

Wood, J. W. \& Ordal, E. J., 1958. Tuberculosis in Pacific salmon and steelhead trout. - Contr. Fish Commn Ore 25, 1-38. 